\title{
Adverse Effects of EDCs on Female Reproductive Organs
}

\begin{abstract}
Jun Kim, Su-bin Choi, Hae-Sic IM and Beum-Soo $\mathrm{An}^{*}$
Department of Biomaterials Science, College of Natural Resources \& Life Science/Life and Industry Convergence Research Institute, Pusan National University, Korea *Corresponding author: An BS, Department of Biomaterials Science, College of Natural Resources \& Life Science, Pusan National University, Republic of Korea, Tel: +82-55-350-5381; Fax: +82-55-350-5389; E-mail: anbs@pusan.ac.kr
\end{abstract}

Received date: Jul 30, 2014; Accepted date: Aug 1, 2014; Published date: Aug 2, 2014

Copyright: (c) $2014 \mathrm{Kim} \mathrm{J}$, et al. This is an open-access editorial distributed under the terms of the Creative Commons Attribution License, which permits unrestricted use, distribution, and reproduction in any medium, provided the original author and source are credited.

\section{Editorial}

Endocrine Disrupting Chemicals (EDCs) are exogenous chemical substances or mixtures that interfere with synthesis, secretion, transport, metabolism, binding action, or elimination of natural endocrine hormones that are present in the body [1]. EDCs are widespread and one of component in persistent pesticides, herbicides, biocides, heat stabilizers, and chemical catalysts, plastic contaminants, pharmaceuticals, or dietary materials. Many EDCs are weakly estrogenic and elicit their actions through the estrogen receptors. The two mammalian receptors for estrogen (ER- $\alpha$ and ER- $\beta$ ) are widely distributed throughout the female reproductive tract $[2,3]$. Therefore, actions of estrogenic EDCs on estrogen receptors may promote abnormalities in estrogen receptor-present female organs such as ovary, uterus, breast, and placenta.

Recently we examined the effect of parabens that were known to have an estrogenic property on the development of ovary [4]. In this study, female pups were given with methyl-, propyl- and butylparabens during neonatal day 1 to 7 . Parabens inhibited early phase of folliculogenesis in the ovaries by regulating expression of folliculogenesis associated genes, AMH, Foxl2, and KITL. In addition, the steroidogenesis in the ovary was also altered by parabens through reduction of StAR and Cyp1lal gene expression. Since parabens are widely used as anti-microbial agents in cosmetic industries, these results suggest that maternal use of cosmetics containing parabens may cause abnormality in folliculogenesis of female infant $[5,6]$.

The effects of EDCs on the uterus that is a major female reproductive organ also studied in our previous studies [7]. The uterus is composed of an endometrium, a muscular myometrium and an outer serosa layer. There are a number of studies showing that EDCs promote endometriosis by increasing proliferation of endometrial cells [8]. However, impact of EDCs in myometrium layer was not understood. In our previous study, we administered immature female rats with bisphenol $\mathrm{A}$, and octylphenol that are well known estrogenic phenolic compounds. The tested EDCs increased expression and localization of contraction-associated proteins including oxytocin receptor and prostaglandin $\mathrm{F}$ receptor, and thereby adversely regulated contractile activity of muscular myometrium in the uterus. Since uterine contraction is related with physiologic function of uterus, exposure to bisphenol A and octylphenol may cause reproductive disorders such as myometriosis, leiomyoma, dysmenorrhea, infertility, preterm labor, abortion, and delayed labor [9-14].

\section{References}

1. Kavlock RJ, Daston GP, DeRosa C, Fenner-Crisp P, Gray LE, et al. (1996) "Research needs for the risk assessment of health and environmental effects of endocrine disruptors: a report of the U.S. EPA-sponsored workshop". Environmental health perspectives 104: 715-740.

2. Pettersson K, Gustafsson J. (2001) "Role of estrogen receptor beta in estrogen action". Annual Review of Physiology 63: 165-192.

3. Lee KH, Hess RA, Bahr JM, Lubahn DB, Taylor J, et al. (2000) "Estrogen receptor alpha has a functional role in the mouse rete testis and efferent ductules". Biology of reproduction 63: 1873-1880.

4. Ahn H, An B, JungE, Yang H, Choi K et al. (2012) "Parabens inhibit the early phase of folliculogenesis and steroidogenesis in the ovaries of neonatal rats". Molecular reproduction and development 79: 626-636.

5. Taxvig C, Vinggaard AM, Hass U, Axelstad M, Boberg J, et al.(2008) "Do parabens have the ability to interfere with steroidogenesis?". Toxicological sciences : an official journal of the Society of Toxicology 106: 206-213.

6. Vo TT, Yoo Y, Choi K, Jeung E(2010) "Potential estrogenic effect (s) of parabens at the prepubertal stage of a postnatal female rat model". Reproductive toxicology 29: 306-316.

7. An B, Ahn H, Kang H, Jung E, Yang H, et al. (2013) "Effects of estrogen and estrogenic compounds, 4-tert-octylphenol, and bisphenol A on the uterine contraction and contraction-associated proteins in rats". Molecular and cellular endocrinology 375: 27-34.

8. Bredhult C, Bäcklin B, Olovsson M(2007) "Effects of some endocrine disruptors on the proliferation and viability of human endometrial endothelial cells in vitro". Reproductive Toxicology 23: 550-559.

9. Missmer SA, Hankinson SE, Spiegelman D, Barbieri RL, Michels KB, et al. (2004) "In utero exposures and the incidence of endometriosis". Fertility and sterility 82: 1501-1508.

10. Igarashi TM, Bruner-Tran KL, Yeaman GR, Lessey BA, Edwards DP, et al. (2005) "Reduced expression of progesterone receptor-B in the endometrium of women with endometriosis and in cocultures of endometrial cells exposed to 2,3,7,8-tetrachlorodibenzo-p-dioxin". Fertility and sterility $84: 67-74$.

11. Bruner-TranKL, Yeaman GR, Crispens MA, Igarashi TM, Osteen KG (2008) "Dioxin may promote inflammation-related development of endometriosis". Fertility and sterility 89: 1287-1298.

12. Dallot E, Pouchelet M, Gouhier N, Cabrol D, Ferre F, et al. (2003) "Contraction of cultured human uterine smooth muscle cells after stimulation with endothelin-1". Biology of reproduction 68: 937-942.

13. Richards PA, RichardsPD, Tiltman AJ (1998) "The ultrastructure of fibromyomatous myometrium and its relationship to infertility". Human reproduction update 4: 520-525.

14. Somigliana E, Vercellini P, Daguati R, Pasin R, De Giorgi O, et al. (2007) "Fibroids and female reproduction: a critical analysis of the evidence", Human reproduction update 13: 465-476. 